normality. The final chapter gives several examples in detail, the emphasis being on 'restitution' therapy, in which enzymes deficient in the tumour are injected into the animal and effects observed on the rate of growth of the tumour. Cessation of growth has been observed as a result of injection of both xanthine oxidase and ribonuclease.

This is not a book for the general reader; it assumes a biochemical background, and an intimate knowledge of a vast literature. Prof. Bergel almost accepts (p. 81) that the fundamental difference between normal and cancer cells must lie in the chemistry of their deoxyribonucleic acids (DNA), and that the changes in enzyme concentration which are observed must necessarily result from this change in the DNA, through mechanisms the study of which is still in its infancy. It follows that attempts to correct enzyme imbalance by 'restitution' therapy cannot restore cancer cells to normality, though its continued application could conceivably control their harmful activities. The attempt to "repair biochemical lesions residing in the DNA" (p. 82) lies far in the future. Enzyme therapy obviously depends on the possibility of introducing macromolecules into cells. The only mechanism so far suggested for this process is pinocytosis (the engulfing of small quantities of extra-cellular fluid by cells), a phenomenon about which little is known with certainty; Prof. Bergel agrees that it is "still a subject of speculation and research" (p. 58).

The subject-matter is presented with exemplary clarity, and the book excellently produced and well indexed. It will obviously be read with the greatest interest by all those concerned in cancer research.

L. H. StICKLAND

\section{PHYSICAL OCEANOGRAPHY}

\section{Physical Oceanography}

By Prof. Albert Defant. Vol. 1: pp. xvi+729. Vol. 2 : pp. viii + 598. (London and New York: Pergamon Press, 1961.) f10 10s. per set of two volumes.

IN these two volumes Prof. Defant has attempted the seemingly impossible task of covering singlehanded the whole field of physical oceanography. That he has succeeded with such thoroughness and in such minute detail reflects the wide range of his lifetime's work in this subject. In almost every chapter, references are found to significant original contributions by Prof. Defant himself, and the text is often illuminated with examples drawn from the results of the Meteor expedition of 1925-27, in which he took part.

Each volume is in two parts ; the first part of Vol. 1 deals with the properties of sea-water and related topics. Following a brief chapter on the dimensions of the oceans and the topography of the sea-floor, the next five chapters, occupying some 200 pages, deal with the physical and chemical properties of sea-water, the distribution of temperature, salinity and density in the ocean and their variation with time, and the temperature-salinity relationship and its connexion with mixing processes. These are followed by two chapters on the water budget of the Earth, and ice in the sea.

The second part of Vol. 1 is devoted to dynamical oceanography, the movement of sea-water in the form of ocean currents. After considering the forces acting on the water, and the basic hydrodynamic equations, the theory of currents in homogeneous water is developed. This is followed by a discussion of the conditions at the boundary surfaces of water masses, and of currents in a non-homogeneous ocean. Special consideration is given to currents in straits, and after a brief discussion-of the effect of wind on the mass distribution and density currents, the remainder of the volume, amounting to 150 pages, is devoted to an account of the general circulation of the oceans.

In Vol. 2, Prof. Defant is concerned with periodic movements in the ocean. The first part deals with the theory of surface waves, methods for their measurement and analysis, and theories of their growth and propagation. Waves in shallow water and near coasts, long waves in canals and standing waves in enclosed basins are also considered. The second part of this volume is an account of the tides and tidal currents. The tide-generating forces, the theory of tides, and the methods of harmonic analysis of tidal observations are deseribed first, followed by a detailed account of the tides in the Mediterranean and the shallow seas. Tides in estuaries are next dealt with; then follows an account of tides in the deep oceans, particularly in the Atlantic. There is a chapter on Earth tides and the effect of friction due to tidal currents, and the volume is concluded with a substantial chapter of 50 pages on internal waves.

The manuscript of this book was completed in 1945, but post-War difficulties prevented its publication until 1961. Several revisions had been made by then, and also the text had been translated from German to English. Inevitably there is some unevenness in the revision; some topics have been brought up to date as far as 1957, others have been relatively neglected. The claim in the preface that "the oceanographic literature has been considered in its entirety to the end of May 1957" seems exaggerated. The first chapter on the structure of the sea-floor is out of date, and post-War revisions have left some confusion. Three different values are quoted for the maximum depth in the Pacific. Much recent work on the topography of the North Atlantic, and the geophysical structure of the Earth's crust beneath the oceans and continents could have been included. In the chapter on properties of sea-water, no mention is made of its electrical conductivity, the precise measurement of which is used extensively nowadays as a substitute for salinity determination. Post-War work in the United States on forecasting ice conditions is not referred to in the chapter "Ice in the Sea". Recent measurements of radiocarbon concentration in sea-water and its implications in estimating the time-scale of the deep circulation are not considered, and much more recent work on the generation and propagation of surface waves could have been mentioned. Besides this lack of uniformity in upto-date revision, the text is marred by a number of misprints, especially in authors' names. But Prof. Defant disarms criticism with his quotation from Newton, that these volumes "may be read with forbearance, ... not so much with the view to censure, as to remedy their defects" ; and indeed these errors and omissions seem minor in comparison with the vast quantity of information presented here.

Physical oceanographers may consider themselves fortunate to have so much of Prof. Defant's knowledge and experience made available to them in these volumes, even at the price of ten guineas.

J. C. Swallow 